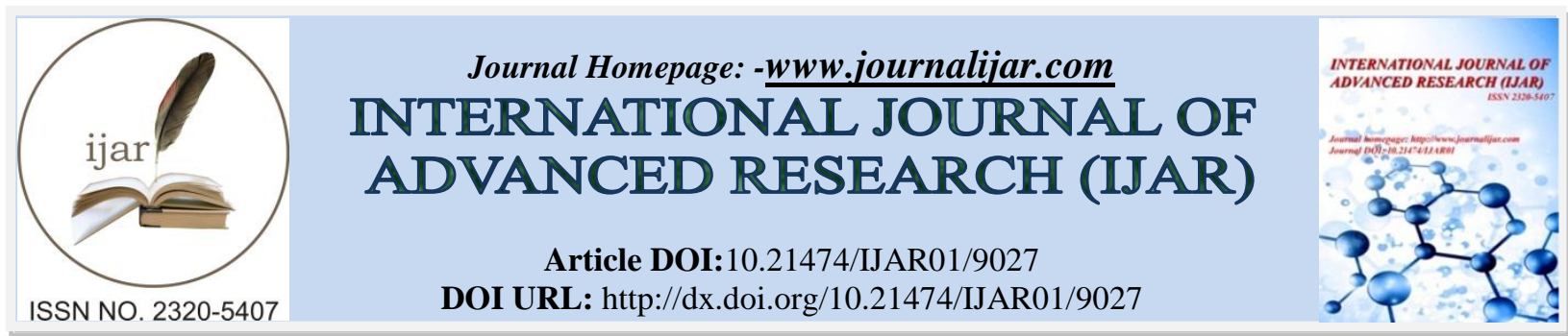

RESEARCH ARTICLE

\title{
CHARACTERISTICS OF THE CONTRACT OF SALE AND LEASE BACK LEASING WITH LESSEE'S LAND AND BUILDING AS OBJECT OF THE CONTRACT.
}

Rachmat HarjonoTengadi ${ }^{1}$, Prof. Dr. Moch. Isnaeni ${ }^{2}$ And Dr. Hj. EndangPrasetyawati ${ }^{3}$.

1. Doctoral Candidate in Law, of the Faculty of Law Universitas 17 Agustus 1945 Surabaya-Indonesia.

2. Emeritus Professor in Law at Universitas Airlangga, Surabaya-Indonesia.

3. Associate Professor in Law and the Head of the Postgraduate (Ph. D) Program in Law at the Faculty of Law Universitas 17 Agustus 1945 Surabaya-Indonesia.

\section{Manuscript Info}

.........................

\section{Manuscript History}

Received: 04 March 2019

Final Accepted: 06 April 2019

Published: May 2019

Key words:-

leasing agreement, sale and lease back leasing, lessee, lessor.

\section{Abstract}

The rapid development in industry and trade in Indonesia must have been dictated by its laws and regulations. One of these laws is sale and lease back leasing in with lessee's land and building is used as the object of the contract that are now utilised by many companies to fulfilled their capital. The legal nature of the concept of a sale and lease back leasing is a contract. The research has found that the concept of sale and lease back leasing with the lessee's land and building used as an object by a financial institution for a collateral. This finding is the unearth by analyzed using Legal Justice Theory, Legal Certainty Theory, and Utilitarian Theory. There has also stages in the contract namely pre-contract stage, contract stage, and post-contract stage. The characteristics of sale and lease back leasing agreement with lessee's land and building were also analyzed using the Contract Theory. As a financial institution in which the lessee sells his land and buildings to the lessor and later the lessor leases it to the lessee. There are principles of contract applicable in the lease agreement i.e., the principles of the contract, the principle of consensualism, the principle of personnel, the principle of good faith, principle of pacta sunt servanda, principle of trust, principle of binding strength, principle of equality in law, principle of balance, principle of legal certainty, moral principle. To support those principles there have also been applied some legal requirements of the contract. Comparing it to the similar types of contract, the sale and lease back leasing is almost having the same characteristics with leasing itself, debt contract, sale and purchase contract, and collateral agreement.As a conclusion, the results of the research as mentioned above, we know that the concepts and characteristics of the sale and lease back leasing is a contract with lessee's land and buildings could be used as an object of the contract. The research has made suggestions, among other things, for the users of the financial institution to use it accordingly to benefit the community as a whole. 


\section{Introduction:-}

In modern civilization, law isan integral partofthesocietylife. The law has a function as a guide to the behavior of community life. In the field of private law, especially in the field of agreement, is formed agreement law which is generally subject toBook III of the Indonesian Civil Code, particularly in the Chapter governing agreement.

The rapid developments in the world of industry and trade has led to the growth of a new type of agreement known as a leasing agreement. In the leasing agreement there is a lessor who has funds/capital and the lessee who needs funds /capital to finance his business activities. Through leasing, the lessee can obtain capital goods by means of a lease to be used for direct production, for which the payment can be paid in installments every month or quarterly to the lessor.

Concerning the rapid growth in the field of leasing finance institutions which is inevitable, in 1974 the Indonesian government in issued a policy to legalise the use of leasing institutions as a form of financing credit agreements in the country. This policy was issued through a type of regulation in the Pancasila system in the form of a Joint Decree of the Minister of Finance, Industry and Trade Number: KEP-122/MK/IV/2/1974 and Number: 32/M/SK/2/1974.

On the other hand, the leasing agreement as a legal entity agreement comes from practices that are not specifically found in Indonesian law. However, it can be estimated that the birth of this leasing agreement made use of the freedom of contract principle, contained in Article 1313 ofthe Civil Code. This freedom of contract principle was regarded as the legal foundation for the birth of the leasing agreement. It has been said so, since the law that regulates lending and borrowing money using this type of contract was considered as obstructed from using the existing funding institutions to serve the needs of this leasing business. It is therefore, in the Indonesian system, leasing would have been indeed be subjected to the General Provisions of the Book III of the Indonesian Civil Code. The Civil Code is a general regulation which regulates civil law relations. However, the Civil Code has been considered as not complete enough to regulate all the legal needs of the parties making a leasing agreement, especially concerning the rights and obligations of the parties.

It was in the beginning that the term leasing was regarded as adopted from the English Legal System called lease, in which, it is used generally as means to renting out properties. In the Indonesian law literatures, one could find that the general definition of leasing has been stated as:

An agreement between Lessor and Lessee to lease a certain type of capital goods produced/sold by the manufacturer/supplier and determined/chosen by Lessee. The right to ownership of the capital goods is remain at the Lessor, while the Lessee has the right to use the capital goods based on the specified lease within a certain period of time. ${ }^{1}$

Based on the definitions stated above, it is understood that in a leasing transaction there are three parties involved, namely: 1. Lessor (leasing company) as the owner of the capital goods; 2. Lessee (company/customer) as the user of the capital goods; and 3. The supplier, as the seller of the capital goods.

Later on, in this research, using the normative legal research ${ }^{2}$ it has been found that the definition of leasing is given in the Article 1 of the Joint Decree of the Minister of Finance, Minister of Industry and Minister of Trade dated 7 of February 1974 Number KEP: 122/MK/IV/2/1974, 32/M/SK/2/1974, 30/Kpts/1/74. It is stated in the Joint Decree that

Leasing is every company financing activity in the form of providing capital goods to be used by anothe company for a certain period of time, based on periodic payments accompanied by option rights for the later company to buy the capital goods or extend the leasing period based on the agreed upon residual value.

Furthermore, according to the Minister of Finance Decree Number 1169 KMK.01/1991 concerning Leasing Activities, leasing is a financing activity in the form of providing capital goods either under a lease with an option

\footnotetext{
${ }^{1}$ Angky Tisnadisastra, Bentuk dan Mekanisme Leasing di Indonesia, Varia Peradilan, Majalah Hukum, Tahun II No. 16, Januari 1987, p.105.

${ }^{2}$ Endang Prasetyawati, Metode Penelitian Hukum, Cetakan Pertama, Nutag Press, 2010, p. 109.
} 
right (finance lease) or leasing without an option right (operating lease) to be used by the lessee for a certain period of time based on regular payments, where as according to the Presidential Regulation of the Republic of Indonesia Number 9 of 2009 concerning Financing Institutions Article 1 point 5: Leasingis a financing activity in the form of the providing of capital goods either by leasing with option rights (finance lease) or lease without option rights (operating lease) to be used by lessee for a certain period of time based on installments payment.

From the definition of leasing above, it turns out that there are two groups of leasing, namely: leasing with option rights (Financial Lease), and leasing without option rights (Operating Lease).

According to Angky Tisnadisastra, Financial Lease is an agreement between Lessor and Lessee where: a. The lessor at the request of lessee will finance the procurement of goods which later belong to the lessor for use by lessee; $b$. The lessor will receive periodic payments from lessee within a specified period of time which the payment obligations of the lessee are non-cancellable and all of them are sufficient to cover all the lessor's financing (capital outlay - cost of funds) and the profits for the lessor. c. The lessee will bear the economic risk of the goods in addition to bearing the maintenance costs and other costs associated with the item (if any). d. Lessee at the end of the lease period has an option right to buy the item with the agreed residual value or extend the lease period with a much lower periodic payment obligation. ${ }^{3}$

Operating Lease, in the other hand is an agreement between lessor and lessee where: a. Lessee agrees to use the services of a lessor for the supply of a good for a relatively short period of time; $b$. The lessor will receive a payment from the lessee whose total amount does not cover the cost of the good and the lessee can usually cancel the agreement anytime. c. The lessor carries the risk of economic and maintenance of the goods. ${ }^{4}$

It is necessary to note the characteristics of leasing generally described by Kartini Muljadi quoting Mr. A. C. Goudsmit and Mr. J. A. M. P. Keijser in his book entitled Leasing van Bedrijfsniddelen, that: (a) Leasing is a method of financing. Of course there are still other aspects of leasing, but the financing aspect is one of the main characteristics of both the Financial Leasing and Operational Leasing which will be explained below; (b) Usually there is a relationship between the lease period and the useful life of the leasing object. This is the main difference with ordinary lease. In general, it can be said that the leasing period in a financial leasing is the same as the economic usefulness of leased objects; (c) The ownership of the leased object is at the lessor. This results in certain impacts, including important impacts in the accounting, such as depreciation and in the legal aspect, in the case of implementing a leasing agreement if there is an injury or default and in the case of bankruptcy. (d) The object of leasing aregoods that are used in a company. The definition of objects used for a company must be given a comprehensive understanding, namely the objects needed to run a company, so not only machines for production, but also motor vehicles and computers for example. ${ }^{5}$

\section{Sale and Lease Back Leasing:-}

Financial Lease activities in Indonesia can be divided into two. They are 1) Direct Financial Lease, and 2) Sale and Lease Back. Direct Financial Lease is a form of leasing transaction in which the Lessor at the request of Lessee buys and therefore pays to the supplier for an item to be leased immediately to the Lessee, while Sale and Lease Back is a form of leasing transaction in which the Lessor at Lessee's request buy from and therefore pay to the Lessee for an item that has been or will soon be owned by Lessee for immediate lease back to Lessee. In general, in Direct Financial Lease and Sale and Lease Back, in the end the leased item is sold to the Lessee based on the Lessee option right to purchase the leasing item. ${ }^{6}$

According to Article 1 number 6 of the Financial Services Authority Regulation Number: 29/PJOK.05/2014 concerning the Implementation of Financing Business Enterprises the definition of Sale and Lease Back is a financing activity in the form of sale of goods by a debtor to a finance company accompanied by re-financing the item to the same debtor.

\footnotetext{
${ }^{3}$ Ibid, p. 106.

${ }^{4}$ Ibid.

${ }^{5}$ Kartini Muljadi, Perjanjian - Leasing, Varia Peradilan, Majalah Hukum, Tahun II No. 16, Januari 1987 , p. 68.

${ }^{6}$ Angky Tisnadisastra, Op.Cit. p. 107.
} 
Until now there are no laws specifically regulating leasing, but according to Gani Djemat, the comprehensive and deeper legal basis underlying lease agreements or leasing activities in Indonesia today includes: a. The principle of legal concordance is based on Article II of the Rules of Transition of the 1945 Constitution on the Civil Law which applies to European citizens; b. Article 1338 of the Civil Code (Burgerlijk Wetboek or abreviated as B.W.) concerning the principle of freedom of contract and general principles of agreement as stated in Chapter I Book III B.W; c. Provisions regarding leasing are listed in Articles 1548 to 1580 of the Civil Code (Book III Chapter VII), insofar as there are no deviations by the parties. d. The provisions of the lease listed in Book III Chapter VII, are generally regulating (Regelend Recht), which means that they can be ruled out by the parties making the agreement. ${ }^{7}$

From the existing leasing regulations, it turns out that the regulations of leasing is more related to economic aspects, this can be understood because leasing is considered as a form of financing which can be seen in each definition of leasing in these regulations is always preceded by the word company financing activities.

In the definition it is not said, that leasing is an agreement as generally said in the provisions in book III of the Civil Code, but if further research is leased it is a legal relationship between a company that provides capital goods for use by other companies and there are periodic payments, there is an option to buy goods based on mutually agreed upon residual values, so it is clear that leasing is an agreement. Therefore, the basis we use in making lease agreements must lead to the basics specified in Book III B.W.

If leasing is an agreement, then questions arise including which agreement, or at least agreement which in Book III of the Indonesian Civil Code is most similar to leasing. By looking at the description of the definition of leasing, legal leasing can be seen as a form of lease which is added with other elements of agreement, such as the provisions of the right to buy and other elements of the agreement. With the existence of various elements in the leasing agency, Djoko Soepadmo, ${ }^{9}$ leaning towards the opinion of legal experts who stated that leasing was a mixed agreement (gemengde overeenkomst), so that the existence of clear laws regarding leasing handling must be adjusted in accordance with various kinds of agreements contained in the leasing.

\section{The Object of the Sale and Lease Back Leasing Agreements:-}

The agreement is regulated in Book III of the Civil Code. Article 1313 of the Civil Code determines that an agreement is an act in which one or more people attach themselves to one or more other people. Professor Moch. Isnaeni has argues, that agreement in the Book III of the Indonesian Civil Code has an open nature. According to Professor Isnaeni, and one of the indicators is that the provisions in the Code are dominated by the provisions that are positioned as a rechtend. ${ }^{10}$

The provisions of article 1319 of the Civil Code, recognize the types of agreements named and agreements not named. The meaning of the agreement named is the types of agreements specifically regulated in Book III of the Civil Code, whereas an nameless agreement is a type of agreement that is not specifically regulated in Book III of the Civil Code. The leasing agreement is an agreement that is not regulated in Book III of the Civil Code.

The agreement referred to in Book III of the Civil Code can fulfill its legal requirements. This means that if one party defaults, the opposing party that is harmed due to default can demand legal compliance with the other party. In this case through a lawsuit to the Court by asking the court to fulfill its demands.

In general, the agreement is not bound to a certain form, can be made orally and if it is made in writing, this is a proof when a dispute occurs. For certain agreements the Law determines a certain form, so that if the form is not followed, the agreement is invalid. Thus the written form is not only merely an instrument of proof, but is a condition for the existence of (bestaaanwaarde) the agreement.

Regarding the understanding of the agreement as mentioned above, the leasing agreement basically does not differ much from the definition of agreement in general. The leasing agreement relates to the financing provided by the

\footnotetext{
${ }^{7}$ Gani Djemat, Soal-soal Hukum yang Dihadapi oleh Industri Leasing Indonesia, Varia Peradilan, Majalah Hukum, Tahun II No. 16, Januari 1987, p.98-99.

${ }^{8}$ Djoko Soepadmo, Tehnik PembuatanAkta Seri B-4 BagianKedua, Bina Ilmu Surabaya, 1996, p.460.

${ }^{9}$ Ibid,p. 462.

${ }^{10}$ Moch. Isnaeni, Pengantar Hukum Jaminan Kebendaan, Revika Petra Media, Surabaya, 2016, p.77.
} 
lessor to the lessee to be used as business capital, although in its development the allocation of business capital through a leasing agreement is intended in accordance with the wishes of the lessor. Leasing agreements are also related to the rights and obligations of the parties as in the agreement in general. The occurrence of a leasing agreement, requires the existence of two parties who bind themselves to an agreement, consisting of a lessor in this case acting as a creditor and a lessee acting as a debtor or party who borrows funds to the lessor.

Regarding to the leasing agreement is not different from the agreement in general, whose arrangements are found in the field of civil law, then in the leasing agreement, of course also subject to the requirements, and procedures for making agreements in general. In connection with that, the enactment of the provisions of Article 1320 of the Civil Code is related to the legal terms of the agreement, namely the agreement of the parties, subject skills, a certain matter, because the halal cannot be avoided in the leasing agreement.

Based on the contract definition stated by Van Dunne, a contract is a legal relationship between two or more people based on an agreement to cause legal consequences. ${ }^{11}$ From this definition, it can be concluded that in making contracts there are three stages, namely: pre-contractual stage which is characterized by supply and acceptance, contractual phase (contractual) is characterized by the existence of agreement or meeting of wills between the parties, and post-contract marked by the implementation of the agreement and/or interpretation of the agreement.

The agreement of the parties in a sale and lease back leasing agreement has begun from the pre-contract stage, namely the lessee submits a lease sale and lease back application to the lessor, then after conducting research on the application the lessor makes a preliminary approval letter to the lessee and as agreement the lessee must sign the letter that is.

Subsequently entering the contract stage, the lessee as the seller signs the sale and purchase agreement of land and buildings that will be alienated to the lessor as a buyer, so that the ownership rights of the land and building are transferred from the lessee to the lessor. Then proceed with the signing of a lease sale and lease back agreement with the object of land and building between the lessor and the lessee by specifying the terms and conditions agreed upon at the pre-contract stage into the leasing agreement. At this stage a debt recognition agreement between the lessee can also be signed to the lessor, and an additional guarantee agreement from the lessee to the lessor.

In the post-contract stage, the lessee will manage the object of leasing in the form of land and buildings and pay the lease money to the lessor. When the lease payment is running, it will arrive at the time the lessee can exercise his right, ie the lessee will buy the leasing object from the lessor.

The skill of the subject of leasing sale and lease back can be seen in article 1329 of the Civil Code, namely that everyone is capable of making agreements if he or she is not legally authorized by law. Article 1330 of the Civil Code determines that a person who is incompetent is a. immature people; b. those who are placed under guardianship. According to Law Number 1 Year 1974 concerning Marriage and Law Number 23 Year 2002 concerning the Protection of Children of the Adult Age, 18 years. Whereas according to article 433 of the Indonesian Civil Code, people who are placed under guardianship are every adult who is always dumb, sick or a dark and wasteful brain. Both the lessor and the lessee as the subject of the leasing agreement must meet the skill requirements to make the leasing agreement. If the lessor and the lessee are legal entities, then they must have a deed of establishment which is authorized by the Ministry of Law and Human Rights, have an official permit, and fulfill the provisions in Law Number 40 of 2007 concerning Limited Liability Companies and Articles of Association.

The definition of the third condition is that a certain thing refers to an item that becomes an object of agreement. According to article 1320 of the Civil Code, goods that are the object of this agreement must be certain, at least the type must be determined. In the case of a sale and lease back agreement, this object is the land and building owned by the lessee that is sold to the lessor. The fourth condition is the reason that halal is related to article 1335 of the Civil Code which states that an agreement without cause or agreement that has been made for a false or prohibited cause has no power. What is meant is because here is the content of the agreement which must be something that is not prohibited by law.

\footnotetext{
${ }^{11}$ M. Natsir Asnawi, Aspek Hukum Janji Pra kontrak, UII Press, Yogyakarta, Desember 2017, h. 21.
} 


\section{Principles in the Sale and Lease Back Leasing Agreement:- The Principle of Freedom Contracts.}

This leasing agreement is a reflection of the principle of freedom of contract in civil law, as stipulated in Article 1313 of the Indonesian Civil Code. If you pay attention to the provisions in Article 1338 of the Indonesian Civil Code, then you can say in a contrario that in principle people are free to make agreements with anyone and about anything, so the principle of freedom of contract is freedom in the material sense. In terms of leasing agreements, of course juridically can be said to have legality, because besides being based on the freedom to make contracts based on the principle of freedom of contract, the making of leasing agreements does not violate applicable laws and regulations, specifically those stipulated in Article 1320 of the Civil Code.

\section{Principle of Consensualism.}

The principle of consensualism is one of the principles contained in the law of engagement. The principle of consensualism focuses on the beginning of the formulation of the engagement or at the time of the pre-contract. If there is no consensus in the pre-contract, no contract will be possible. The consensus word comes from Latin consensus which means general agreement or collective opinion. Other terms in English are known as the term consent, which means approval, agreement, or licensing for an action or purpose that is given voluntarily by a competent person, legally agreeing. ${ }^{12}$

Based on the principle of consensuality, some scholars state that consensus is the birth of an agreement, or that an agreement has been born when an agreement between the parties has taken place, and such an agreement is legitimate without requiring a formality.

In a leasing agreement, the principle of consensus also remains the main element, because without an agreement between the lessor and the lessee, the leasing agreement will not be possible. In other words, before the leasing agreement between the leasor and the lease occurs, in the pre-contract period, a bid and negotiation is carried out between the prospective lessor and the lessee candidate. This negotiation is certainly to obtain agreements or in legal language known as consensus to obtain agreements related to the contents of the contract to be carried out.

The leasing agreement will only be realized when the parties have reached an agreement related to the content or content of the agreement, the object of leasing, the method of payment, the interest on the loan, the risk of default, the leasing time, etc. If these agreements have been reached, a new leasing agreement can be implemented.

\section{Principle of Pacta Sunt Servanda.}

The principle of pacta sunt servanda is one of the principles in the agreement that applies universally. This principle is also called the principle of legal certainty. M. Natsir Asnawi borrowed the definition of pacta sunt servanda principle from Miranda Mayuri Pillay as follows: Pacta sunt servanda states that the obligation or agreement must be honored; therefore parties who enter into the contractual agreement with the relevant intention are obliged to respect the agreement. The principle of pacta sunt servanda is etymologically meaning the agreement is binding as a Statute. ${ }^{13}$ The parties that make the agreement are bound by the contents of the agreement that they have made, so that their power is equated with the power of binding a law for citizens. This principle is regulated in article 1338 paragraph (1) of the Indonesian Civil Code which states that: All agreements that are legally made apply as laws for those who make them.

The existence of the principle of pacta sunt servanda in leasing agreements is a fact that cannot be avoided. In any agreement this principle is not a problem that needs to be searched for. By mutatis mutandis every agreement made by the parties legally by following the conditions specified in Article 1320 of the Indonesian Civil Code, it must be legally obligatory for the parties to obey it. This means that the agreement is a law made by the parties and binding itself.

\section{Principle of Equality in Law.}

This principle places the parties in equality, there is no difference, even though there are differences in skin, nation, wealth, power, position and others. Each party must see this equality and require both parties to respect each other as human beings created by God Almighty, as stipulated fundamental principle in Pancasila.

\footnotetext{
${ }^{12}$ Fajar Sugianto, Hukum Kontrak, Setara Pers, Malang, 2014, p.8.

${ }^{13} \mathrm{Ibid}$, h.15.
} 
In a leasing agreement, the parties are in the same position or position as the party to the agreement. Indeed, there must be a difference between parties, but the difference lies only in the economic position of the parties. The lessor has a higher position, because the lessor financially has sufficient funds, while the lessee is economically insufficient, so the lessee needs funds from the lessor to finance the lessee in running his business.

\section{Principle of Fairness}

This principle requires both parties to fulfill and implement the agreement. This principle of balance is a continuation of the principle of equality. Creditors have the power to demand achievements and if necessary can demand repayment of performance through the debtor's wealth, but the creditor also bears the burden of implementing the agreement in good faith. It can be seen here that the position of a strong creditor is balanced with its obligation to pay attention to good faith, so that the position of creditors and debtors is balanced.

In a leasing agreement, the rights and obligations between the parties are in a balanced position, meaning that the parties have agreed together in relation to the agreed achievements in the leasing. Based on the principle of consesualitas, if the position of one party feels lower (unbalanced) then the other party can refuse to continue the agreement. In this agreement the parties are free to determine the rights and obligations that must be borne by each party equally.

\section{Conclusion:-}

The Characteristics of leasing sale and lease back agreements with land and building objects belonging to the lessee is basically a financing agreement or a contract with the lessor as a party that provides funds/capital and the lessee as a party that needs funds/capital. In this lease sale and lease back agreement, the object of the agreement is fixed objects such as land and buildings owned by the lessee that are sold first to the lessor. The leasing object that has been turned into the property of the lessor does not have to be controlled by the lessor, but remains in the control of the lessee who uses or operates the leasing object. In the agreement the refund leasing is carried out by way of regular lease payments. In addition, in the leasing financing agreement, there is an option for the lessee to buy goods or objects that are the object of the leasing agreement after a certain period of time agreed in the leasing agreement, or continue the leasing agreement until the lease period ends.

It is suggested that leasing agreement is a breakthrough in business law in Indonesia that requires a new legal framework to ensure legal certainty and justice. For this reason, it is recommended to the legislators to form a Law on Leasing, because the Book III of the Indonesian Civil Code does not or does not yet regulate.Since leasing sale and lease back financing is an object, the lessee's movable and immovable property is sold to the lessor before the leasing financing agreement is carried out, so it is recommended that a clear regulation is taken to create justice, legal certainty and benefit for the parties, especially related to the clauses in the agreement and the legal consequences that arise for the parties in the lease, namely the lessee and the lessor.

\section{Bibliography:-}

1. R. Subekti, dan R. Tjitrosudibio, Kitab Undang-Undang Hukum Perdata, Cetakan Ketigapuluh Delapan, Pradnya Paramita, Jakarta, 2007.

2. Djoko Soepadmo, Tehnik Pembuatan Akta Seri B-4 Bagian Kedua, Cetakan Kedua, Bina Ilmu Surabaya, 1995.

3. Fajar Sugianto, Hukum Kontrak, Setara Pers, Malang, 2014.

4. Moch. Isnaeni, Pengantar Hukum Jaminan Kebendaan, Revika Petra Media, Surabaya, 2016.

5. M. Natsir Asnawi, Aspek Hukum Janji Prakontrak, UII Press Yogyakarta, Yogyakarta, 2018.

6. Endang Prasetyawati, Metode Penelitian Hukum, Cetakan Pertama, Fakultas Hukum Universitas 17 Agustus 1945, Surabaya, Untag Press, Surabaya, 2010.

7. Angky Tisnadisastra, Bentuk dan Mekanisme Leasing di Indonesia, Varia Peradilan, Majalah Hukum, Tahun II No. 16, Januari 1987.

8. Gani Djemat, Soal-soal Hukum yang Dihadapi oleh Industri Leasing Indonesia, Varia Peradilan, Majalah Hukum Tahun II No. 16, Januari 1987.

9. Kartini Muljadi, Perjanjian-Leasing, Varia Peradilan, Majalah Hukum Tahun II No. 16, Januari 1987.

10. Mohamad Idwan Ganie, Kontrak Leasing, Varia Peradilan, Majalah Hukum Tahun II No. 16, Januari 1987. 